\title{
Selecting Partner Countries for Preferential Trade Agreements: Experimental Evidence From Costa Rica, Nicaragua, and Vietnam
}

\author{
Gabriele Spilker \\ University of Salzburg \\ ThOMAS BERNAUER \\ ETH Zurich \\ AND \\ Víctor UMAÑa \\ INCAE Business School
}

\begin{abstract}
Preferential trade agreements (PTAs) constitute the most rapidly growing form of trade liberalization in the global economy. In contrast to, for example, the World Trade Organization, PTAs allow for discrimination among potential partner countries. This helps explain their proliferation. But it also raises an important question: which countries are preferred partners for PTAs? On the presumption that public opinion matters—both normatively and analytically—for trade policy, we study what types of countries citizens prefer for PTAs. We focus on developing countries, as they both play an increasingly important role in the expanding global network of PTAs and also remain understudied in the literature on international cooperation and trade policy. To account for the multidimensionality of PTA partner country choice, we develop and test a theoretical framework through conjoint experiments embedded in national surveys in Costa Rica, Nicaragua, and Vietnam. The results show that, despite starkly divergent national contexts, citizens in all three countries opt for similar partner countries. Respondents prefer culturally similar countries, democracies, and countries that maintain high environmental and labor standards. Somewhat surprisingly, economic size and geographic distance prove less important in the choice of which countries to support as PTA partners.
\end{abstract}

The rapid proliferation of preferential trade agreements (PTAs) is one of the most striking features of the contemporary world economy. Perhaps the key reason for their popularity is that they provide the possibility to discriminate among potential partner countries (Dür, Baccini, and Elsig 2014; Mansfield and Milner 2012). But this raises the question of how countries choose their PTA partners. Despite the expansion of macro-level research on this topic (Baccini and Urpelainen 2012; Baccini and Dür 2012; Baier and Bergstrand 2004; Baier, Bergstrand, and Clance 2014; Baldwin 2011; Dür et al. 2014; Egger and Larch 2008; Manger and Shadlen 2014; Mansfield and Milner 2012), almost no systematic research exists on the micro-level foundations of PTA partner-country choice. Thus, we attempt to

Gabriele Spilker is Assistant Professor of International Politics at the Department of Political Science and Sociology of the University of Salzburg. Her main research interests are in the area of international political economy, international cooperation, globalization and environmental politics.

Thomas Bernauer is a professor of political science at ETH Zurich and director of ETH Zurich's Institute of Science, Technology and Policy. In his research and teaching he focuses on international environmental and trade issues.

Víctor Umaña is a PhD candidate in Political Economy at ETH Zurich and associate director of the Centro Latinoamericano para la Competitividad y el Desarrollo Sostenible (CLACDS) at INCAE Business School in Costa Rica.

Author's note: We would like to thank Andreas Dür, Manfred Elsig, Mark Manger, Daniel Nielson, Brad Parks, Jessica Fortin-Rittberger, the members of the political economy research group at ETH Zurich, the participants of the political science colloquium at the University of Salzburg and the participants of the 8th Annual Conference on The Political Economy of International Organizations, the Journal's Editors as well as three anonymous reviewers for very helpful comments on earlier versions of this article. The data collection for this paper was funded by the Swiss National Center for Competence in Research (NCCR) "Trade Regulation." discern those characteristics that make countries more (or less) popular as international trade partners from citizens' perspectives.

Although citizens only rarely vote directly and specifically on international trade issues, public opinion plays an important role in trade policymaking (Kono 2008; Mansfield and Milner 2012). As trade liberalization efforts in recent years increasingly shift from the global to regional and bilateral levels, the characteristics of (potential) trade partner countries move to the forefront of public discourse on this topic. The current public backlash in both the United States and Europe with regard to several trade agreements presently under negotiation, such as the Transpacific Partnership (TPP) and the Transatlantic Trade and Investment Partnership (TTIP), demonstrates the importance of understanding what considerations shape citizens' attitudes with respect to PTAs and to the countries involved.

However, public debate on PTAs occurs beyond advanced industrialized countries. Costa Rica, for example, held a national referendum on ratification of the Free Trade Agreement between the Dominican Republic, Central America and the United States (CAFTA-DR). The power and economic asymmetry between Costa Rica and the United States became the central controversy of the campaign. CAFTA-DR also generated extensive media coverage in the United States, received reference in several electoral campaigns, and emerged as the most controversial vote on a trade agreement in the US Congress since NAFTA (Guisinger 2009; Hicks, Milner, and Tingley 2014; Hornbeck 2008; Urbatsch 2013).

Moreover, a number of additional reasons suggest the need for scholars of international cooperation-and 
international trade in particular-to understand the views and preferences of "ordinary citizens" with respect to PTAs and PTA partner countries. First, various macro-level theories on PTA formation make important but largely untested assumptions concerning individual-level preferences. For example, scholars explain the empirical finding that cultural similarity increases bilateral trade flows (Dow 2006; Dow and Karunaratna 2006; Guiso, Sapienza, and Zingales 2009) via an-alleged, but untested-micro-level mechanism. The latter presumes that cultural similarity furthers the flow of information in economic exchange and allows businesses to learn about partners, thus reducing uncertainty. Studying public opinion on PTA partner country choice therefore helps us better understand whether such micro-level assumptions are empirically valid.

Second, though we already know a lot about citizens' preferences vis-à-vis trade liberalization in general, we know very little about preferences vis-à-vis preferential trade. The rich and detailed literature on individual trade preferences (Baker 2003, 2005; Beaulieu 2002; Beaulieu, Yatawara, and Wang 2005; Blonigen 2008; 2011; Fordham and Kleinberg 2012; Mansfield and Mutz 2009; Mayda and Rodrik 2005; O'Rourke and Sinnott 2001; Scheve and Slaughter 2001) focuses on why individuals support or oppose reducing trade barriers in general (with respect to all other countries). Yet, due to the possibility of discriminating between partner countries, preferential trade agreements differ from the usual scenario of trade liberalization. This difference should also find reflection in individual level preferences.

Third, in studying public opinion on PTA partner country choices in three developing countries, we advance our general knowledge of public opinion in developing countries. This perspective from the Global South adds important insights to what we know from empirical studies on industrialized countries (Acharya and Buzon 2007; Hicks and Kim 2012). One example concerns environmental and labor standards, where richer and poorer countries commonly differ considerably (Franzen and Meyer 2010) and which matter for trade liberalization. Another example concerns the implications of cultural similarity and political system characteristics.

One significant challenge to studying citizens' preferences concerning potential PTA partners resides in the multidimensionality of partner country choice. That is, potential partner countries vary with regard to the size of their economy, culture, political system, social standards, and other factors, and we need to consider these different characteristics at both the theoretical and empirical level. We account for the multidimensionality of partner country choice by developing a theoretical framework that identifies empirical implications for a set of specific partner country characteristics (geographic distance and economic size, cultural similarity, political system, security alliances, and social and environmental standards). Each of our five hypotheses thus states whether the respective country characteristics will likely increase (or decrease) citizen support for a PTA with a corresponding potential partner country.

We test these hypotheses empirically using conjoint analysis, an experimental approach well-suited for analyzing multidimensional phenomena. In our choice-based conjoint experiments, we confronted respondents, in stylized form, with potential trade partner countries that varied with respect to theoretically relevant characteristics (such as political system, economic size, and so forth).
Respondents had to choose between pairs of potential PTA partner countries and to rank each potential partner separately. Because the different attributes (for example, type of political system) of each hypothetical country profile are designed as experimental treatment conditions assigned randomly to participants, researchers can estimate the relative influence of each attribute value on the resulting choice or rating of (hypothetical) partner countries (Hainmueller, Hopkins, and Yamamoto 2014).

We embedded our experiment in surveys administered to national random samples in three developing countries: Costa Rica, Nicaragua, and Vietnam. We chose these three countries because they differ strongly with respect to income levels, political system, and environmental and social standards. In studying public opinion in these countries, we aimed to explore whether the particular features of potential PTA partner countries that theoretically should make them more popular are empirically relevant across very different economic and political contexts in the Global South.

The empirical results show that individuals in the three countries opt for very similar trade partners, despite significantly different home country contexts. They prefer to trade with economies of similar or larger size, which is in line with conventional gains from trade arguments, whereas (geographic) distance has no effect. Cultural similarity proves more important than these economic considerations, however, since individuals strongly prefer culturally similar PTA partners. In contrast to our expectations and despite very different political systems and income levels, citizens in Vietnam, Nicaragua, and Costa Rica do not significantly differ in their evaluation of a (potential) partner country's political system and its labor and environmental standards. For example, we observe that individuals in the two poorer countries (Vietnam and Nicaragua) prefer to trade with countries that have higher environmental and labor standards. Similarly, not only do respondents in Costa Rica and Nicaragua prefer PTAs with (other) democratic countries-which is what we expected-respondents in Vietnam (an autocracy) also favor democratic PTA partner countries. Finally, contrary to the claims of relative gains arguments on trade, security considerations seem to play only a very minor role.

The next section develops the theoretical argument, which focuses on the effects of geographic distance and the economic size of potential PTA partners, psychic distance, political regime type, security ties, and environmental and social standards. We then describe the empirical design of the study before presenting the results and discussing their implications for research and policymaking.

\section{Trade Partner Choice - a Multidimensional Decision}

Selecting one PTA partner country over another is a multidimensional choice. Potential partner countries vary with respect to economic size, culture, political system, and other attributes. We build on both macro-level trade theories and micro-level evidence from advanced industrialized countries to identify characteristics that should be important for citizens' preferences.

In particular, we consider the following partner country characteristics: geographic distance and economic size, cultural similarity, political system, security alliances, and social and environmental standards. For each of these factors, we make predictions as to whether the respective attribute will increase (or decrease) citizen support for a PTA with the respective potential partner country, 
depending on the respondent's home country. Due to differing home country contexts (such as autocratic versus democratic political systems and level of economic development), individuals from Costa Rica, Nicaragua, and Vietnam could hold different preferences as to which country characteristics make a partner more (or less) attractive.

\section{Distance and Economic Size - Consumer Gains}

The most prominent economic explanation of international trade flows-and thus implicitly of government and market choices of trade partner countries as well-relates to gravity in physics. Thus, scholars call it the "gravity model." It explains bilateral trade flows in terms of countries' economic size and their geographic distance: it predicts that pairs of countries will trade more if they are closer to each other in terms of geographic distance and if their economies are larger (Tinbergen 1962). Recent studies extend this model to trade disputes. They show that dispute incidence is a function of economic size and bilateral trade volumes (Sattler and Bernauer 2011). Other studies apply it to PTA formation and demonstrate that PTA formation becomes more likely with, on the one hand, growing economic size of at least one country in a dyad and, on the other hand, a shorter distance between them (Baier and Bergstrand 2004; Baier et al. 2014; Dür et al. 2014; Linders, Burger, and van Oort 2008).

Why should economic size and geographic distance affect how citizens evaluate a potential trade partner? We argue that economic size and geographic distance should affect citizens' attitudes because they transmit relevant cues about the agreement's economic benefits, from both a consumption perspective and a wage-related perspective. We submit that individuals should value economic size when forming preferences for (or against) potential PTA partner countries because trade with a larger country will likely result in increased consumption possibilities. Therefore, we expect individuals to associate an economically larger PTA partner country with higher economic gains emanating from a more diverse and potentially cheaper set of imported goods (Baker 2003, 2005; Grossman and Helpman 1995).

In addition to this consumption perspective, citizens in developing countries should prefer trade agreements with larger economies because of the increased export opportunities for domestic firms due to the large market size (Shadlen 2005, 2008). In most developing countries, people mainly compete on the basis of low-skilled wages. Hence a PTA with a bigger economy should be associated with wage increases for low-skilled workers because of comparative advantage (Caves, Frankel, and Rose 2002, Oatley 2010). Moreover, developing countries often become dependent on access to developed country markets via preferential schemes, such as the generalized system of preferences (GSP) (Manger and Shadlen 2014). Though workers may not know the specific details of such preferential schemes, they should know that many of the goods they produce are exported to larger economies. Due to this link, many individuals in developing countries will be aware that their jobs and wages are closely tied to exports to larger economies. Thus, they should strongly value a PTA offering access to a larger export market for their home country's products.

Hence we expect that trade with larger economies is likely to be more attractive than trade with economies of similar size, or with smaller economies, all else equal.
Here, all else equal means, for instance, that we need to control for security relations: larger economies (tending to have stronger military capabilities) may pose security threats to smaller economies. For example, the most proximate large economy to Vietnam is China, and relations between the two countries are quite strained due to military-security rivalries. The most proximate large economy to Costa Rica and Nicaragua is the United States. The quality of security relations among the three countries differs-with territorial disputes between Costa Rica and Nicaragua and a history of American military intervention in Nicaragua.

The second component of the gravity model holds that countries tend to trade more with more geographically proximate countries. This is because greater distance involves higher transportation costs, reducing the benefits of trade. At the micro-level, individuals are likely to draw similar conclusions as distance should act as a heuristic for the costs associated with the exchange of goods and services between the two trading partners. As in the case of economic size, physical distance could affect PTA partner country choice through its link via a third variable, in this case cultural similarity. Since physical proximity is likely to contribute to familiarity, which in turn could increase trust, reduce uncertainty, and thus reduce transactions costs more generally (Kaltenthaler and Miller 2013; Spilker, Schaffer, and Bernauer 2012), geographically closer countries should be preferred trade partners. However, we control for this link by explicitly taking cultural similarity into account (see below).

In summary, translating this second component of the gravity model from the macro- to the micro-level, we expect that citizens prefer trade with geographically more proximate countries, all else (for example, cultural similarity and security relations) equal.

H1: Individuals are likely to prefer PTAs with larger economies and with geographically more proximate countries.

\section{Psychic Distance}

Various studies note that distance should be understood in broader terms than simply geography. Scholars have coined the term "psychic distance" to denote a set of less tangible factors that may also explain resistance to (or support for) trade. In particular, several authors note that similarities in culture, religion, and language are likely to be important determinants of PTA formation (Dür et al. 2014; Frankel, Stein, and Wei 1998; Liu 2010; Mansfield and Milner 2014; Rauch 1999; see also Simmons and Elkins 2004). Though a broadened definition of psychic distance could also include similarity of political regime type, security relations, and environmental and labor standards (Gowa and Mansfield 1993; Mansfield and Milner 2012, 2014), we treat these factors separately (see below).

Our argument for why culturally similar countries are likely to trade more with each other is based on arguments about psychological ingroup-outgroup feelings, national images, and economic considerations. Findings from business, marketing, and social psychology research indicate that individual predispositions toward other countries, rooted in culture, are important determinants of economic exchanges and thus of individual trade preferences (Guiso et al. 2009; Klein 2002; Klein, Ettenson, and Morris 1998; Verlegh and Steenkamp 1999). At the individual level, consumer-based theories of political preferences suggest that individuals are more likely to form their trade policy preferences according 
to their own patterns of personal consumption, rather than their status as producers or income earners (Baker 2003, 2005; Rho and Tomz 2012). Consumers tend to rely on heuristics from national images when making purchasing decisions. Individuals are thus primed by country-of-origin cues to feel and behave in predictable ways (Ehrlich 2010; Hearn 2013). ${ }^{1}$

The idea that cultural similarity acts as an informational heuristic is also at the center of several macro-level studies examining how differences in psychic distance influence bilateral trade flows (Dow 2006; Dow and Karunaratna 2006; Guiso et al. 2009; Linders et al. 2008; Rauch 1999). Most of these studies find that differences in language, education, and political systems have a statistically significant trade-inhibiting effect and interpret this result to mean that these factors restrict the flow of information in economic exchange and constrain businesses' ability to learn about partners, thus generating uncertainty. Hence the macro-level phenomenon that larger psychic distance reduces trade flows is explained via a (presumed, but untested) micro-level mechanism associated with learning and uncertainty reduction.

With regard to PTA partner country preferences, we expect cultural similarity to act as an informational cue akin to the mechanism just described. ${ }^{2}$ If another country's population speaks the same language and shares a similar religious background, this should signal to people that information should flow easily alongside economic exchanges, thus reducing uncertainty. Perhaps even more important, commonality between languages and religions should affect PTA partner country preferences via its effect on bilateral trust (how much individuals in one country trust people from the other country) (Guiso et al. 2009). Cultural commonalities concerning religion, history of conflicts, and genetic and somatic factors (whether people look alike) affect trust. Since lower levels of trust are associated with less economic exchange between two countries and consequentially have a negative effect on free-trade preferences (Kaltenthaler and Miller 2013; Spilker et al. 2012), we expect psychic distance to influence PTA partner preferences via the effect on trust. Individuals should thus prefer PTAs with countries that share a similar cultural background. For the three countries our empirical analysis focuses on, this means respondents from Nicaragua and Costa Rica are likely to prefer Spanishspeaking and Christian countries, whereas respondents from Vietnam are likely to favor countries from the Buddhist and/or Lunar Year tradition.

\section{H2: Individuals are likely to prefer PTAs with culturally similar countries.}

\section{Political Regime Type}

Several studies show that shared (dyadic) democracy is one of the strongest predictors of PTA formation

${ }^{1}$ Verlegh and Steenkamp (1999) argue, for instance, that the country of origin affects consumer product evaluation through three mechanisms: cognitive, affective, and normative. As such, the country of origin is a cue for product quality, signaling attributes such as reliability or durability (cognitive). At the same time, it is an image attribute that links the product to symbolic and emotional benefits (affective). Moreover, as consumers hold social and personal norms related to the country of origin, purchases from countries with objectionable activities or regimes may be deemed unacceptable (normative).

${ }^{2}$ It should be noted at this point that our empirical analysis captures country characteristics in stylized form and does not refer to specific countries by name (Drezner 2008; Fordham and Kleinberg 2011; 2012; Gray and Hicks 2014; Morrow, Siverson, and Tabares 1998) for reasons explained further below.
(Mansfield and Milner 2012; Mansfield, Milner, and Pevehouse 2008). With regard to citizens' preferences, we expect the political system to play an important role as well, primarily for two reasons: common value systems and respect for the rule of law.

Somewhat similar to the psychic distance mechanism discussed above, sharing the same political system could signal that the respective partner country and its population subscribe to the same general sociopolitical value system. According to this logic, individuals in democracies should prefer trade partners that have the same political institutions, such as free and fair elections, because they expect these countries to share similar interests (Russett and Oneal 2001; Tomz and Weeks 2013). Entering into a PTA involves a potentially costly mutual commitment to lower barriers to goods and services exchange, so people are likely to find it more acceptable to enter such an agreement with a partner country that shares the same basic political values (such as political rights and civil liberties). However, in the case of autocracies, such as Vietnam, it is somewhat difficult to imagine what-from an individual's perspective-a similar value system should consist of. Though a shared political ideology, such as communism, might offer such a mechanism, we consider this unlikely in the Vietnamese case because of the strained relationship with China.

In contrast, the second argument as to why political regime type should matter for PTA partner country preferences should hold independently of the home country's political system. This argument centers on individuals' expectations concerning the extent to which the partner country will abide by the rule of law and, by extension, the agreed-upon PTA rules. The existing literature typically acknowledges that democracies are by and large characterized not only by electoral competition but also by higher respect for the rule of law (Li 2006). If, at the micro-level, individual citizens are aware of this, they are likely to expect democracies to abide by and respect the rules of trade agreements and are thus likely to prefer PTAs with democracies.

The arguments just discussed generate unambiguous predictions for democracies, such as Costa Rica and Nicaragua. ${ }^{3}$ Individuals in both countries are likely to prefer other democracies as PTA partners for both reasons outlined above: they should view other democracies as sharing a joint value system and should expect greater compliance from these partners.

What to expect in the Vietnam case is less clear. If we view political regime type as a psychic distance factor, it is not obvious how citizens in Vietnam value a democratic partner country (on average) in contrast to an autocratic partner country-controlling for other factors, such as the fact that many democracies are richer than Vietnam and are thus potentially attractive trade partners because of their economic size. However, if Vietnamese citizens expect greater compliance by democracies (due to stronger rule of law in these countries), they should prefer PTAs with democracies.

In summary, we expect respondents from Costa Rica and Nicaragua to favor PTAs with democracies while

\footnotetext{
${ }^{3}$ According to the Polity IV dataset, both countries are classified as democracies (Costa Rica has a Polity value of 10 for all years Polity IV is available and Nicaragua has a Polity value of 8 or above since 1995) (Marshall, Jaggers, and Gurr 2006).
} 
theory does not enable unambiguous prediction in the Vietnamese case.

H3: Individuals from democratic countries are likely to prefer PTAs with democratic countries.

\section{Military and Security Alliances}

Several empirical studies have found that countries are more likely to establish PTAs with countries sharing security/military ties (Gowa and Mansfield 1993; Mansfield and Milner 2014). The argument here is that PTAs among members of a security/military alliance can contribute to the alliance's overall capacity, since trade gains help enhance the parties' military capabilities (Gowa and Mansfield 1993). Conversely, countries have little incentive to form a PTA with an adversary due to security externalities that might result from gains from trade (Drezner 2008; Gowa and Mansfield 1993; Morrow, Siverson, and Tabares 1998). For the same reasons, concern about asymmetric relative gains from trade is likely to diminish if two countries have closer security ties (Grieco 1988; Liberman 1996).

Translating this argument from the macro- to the microlevel implies that individuals should prefer partner countries with which they already have security ties because they are likely to expect their allies to use gains from trade for purposes of mutual interest. In addition, if citizens are aware or believe that trade can create unequal relative gains that might translate into military advantages, opting for a PTA partner country that is already an ally will mitigate potential security fears. Consequently, we expect individuals to prefer PTAs with security allies, all else equal.

However, historical context is likely to matter and may result in differences across the three countries in our empirical focus. Vietnam and Nicaragua experienced prolonged military conflicts in the latter part of the twentieth century, with the United States as the main adversary. Both countries have active armies with influential roles in politics, and security/military concerns are important for political and economic elites as well as the mass public. While the conflict between Nicaragua and the United States has subsided in the past 20 years, the US-Vietnamese conflict has been replaced by security problems between Vietnam and China. For these reasons, we expect the hypothesized effect to be stronger in the Vietnamese case than in Nicaragua, and there is likely to be no such effect in the Costa Rican case. The latter abolished its army in 1949 and successfully isolated itself from the Central American armed conflicts of the twentieth century.

H4: Individuals are likely to favor PTAs with security allies. This effect is likely to be strongest for Vietnam, followed by Nicaragua, and is likely to be non-significant in Costa Rica.

\section{Environmental and Labor Standards}

PTA negotiations have become particularly prominent fora for linking trade with labor and environmental standards because they are more flexible legal instruments than global trade policymaking in the World Trade Organization (WTO) (Cottier 2002; Hafner-Burton 2005; Spilker and Böhmelt 2013).

Social and environmental policies differ quite strongly across countries (Bernauer and Böhmelt 2013). Arguments about post-material value systems-particularly prominent in the literature in this field-hold that variation in environmental and social policy preferences is influenced mainly by per capita income differences: as individuals become richer, their demand for social policies and higher environmental standards grows (Anderson 1997; Bechtel, Bernauer, and Meyer 2012; Ferrantino 1997; Franzen and Meyer 2010; Spilker 2013).

Translated to the context of PTAs, Anderson (1997) argues that PTAs involving advanced economies have more social and environmental provisions than those between developing countries because demand for these policies is income elastic, and barriers to trade tend to be lower among developed countries than those between developed and developing countries or among developing countries (Anderson 1997). Hence citizens' demand for PTA partners with similar or higher environmental and social standards should increase with a country's economic development level. Consequently, one should expect citizens from developing countries, unlike those from advanced economies, to prefer PTAs with countries that have lower or similar environmental and labor standards due to lower demand for environmental and social protection in those countries.

Again, however, we need to pay attention to historical and economic context and therefore expect some differences between the three countries of interest. Costa Rica is an upper middle-income economy with a long-standing tradition of social and environmental protection. It ranks first in Latin America and twenty-fifth in the world on the Social Progress Index, which measures social and environmental performance alongside GDP (Porter, Stern, and Green 2014). After Haiti, Nicaragua is the second poorest country in the Western Hemisphere. Poverty and unemployment are widespread, and environmental and labor standards are relatively low and poorly enforced. The country ranks at the bottom of the Environmental Performance Index in items related to forest and water access and protection (EPI 2014). Nicaragua competes in the global arena primarily on the basis of low-skilled labor and natural resources (Sala-I-Martin and Schwab 2012). Vietnam has experienced impressive economic growth since the implementation of the doi moi reforms, but social and environmental performance is weak. Like Nicaragua, Vietnam competes on the basis of price, selling basic products and commodities, with low productivity reflected in low wages (Sala-I-Martin and Schwab 2012). Environmental degradation and poorly enforced standards are well documented by government, and international and foreign aid organizations (Loan 2011; Vietnam News 2013). The Environmental Performance Index ranks Vietnam $136^{\text {th }}$ of 178 countries, implying that the country is one of the worst environmental performers among ASEAN economies (EPI 2014).

We expect these different contexts to have implications for citizens' preferences for PTA partners with higher (or lower) environmental and labor standards. In both Nicaragua and Vietnam, low labor and environmental costs form part of the general economic strategy of competing on prices in labor and natural resource intensive products. In contrast, the Costa Rican economy's characteristics and existing environmental and social policies suggest that there should be more demand for social and environmental protection. Therefore, we expect respondents from Costa Rica to favor PTA partner countries with similar or higher environmental and social standards, whereas the effect should be less pronounced or reversed in Nicaragua and Vietnam. ${ }^{4}$

${ }^{4}$ For a contrasting argument, see Bernauer and Nguyen (2015) 
H5: Individuals in Costa Rica are likely to prefer PTAs with countries that have similar or higher environmental and labor standards. This effect should be less pronounced or reversed in Nicaragua and Vietnam.

\section{Empirical Design}

To empirically assess the importance of particular country characteristics for PTA partner choices, we implemented conjoint experiments, an approach well-suited for analyzing multidimensional phenomena (Green, Krieger, and Wind 2001; Hainmueller et al. 2014). The experiments were embedded in surveys administered to national random samples in Costa Rica, Nicaragua, and Vietnam. Appendix 1 lists an overview of the main characteristics and differences between the three countries, which formed the basis of our country selection.

The three population-based survey experiments were implemented from December 2013 to February 2014. They were administered face-to-face to representative samples of the respective population aged 18 to $64 .^{5}$ Sample sizes were 820 in Costa Rica, 800 in Nicaragua, and 700 in Vietnam. Our surveys in Costa Rica and Nicaragua covered the entire country. In Vietnam we restricted the sampling to the Hanoi and Ho Chi Minh City (HCMC) areas, which also include large rural districts. The latter restriction was necessary for logistical and cost reasons. As shown by Nguyen and Bernauer (2014) the socio-demographics of these two areas are very similar to the sociodemographics of the country as a whole. ${ }^{6}$

In conjoint experiments, much like in the real world of policymaking, researchers confront respondents with options (profiles) that vary on several dimensions (attributes) and ask respondents to state their preferences with regard to the overall profile. This approach tends to mitigate problems of social desirability because respondents do not have to reveal which attributes of an option they find more or less attractive. Conjoint experiments therefore allow for simultaneous testing of several causal hypotheses as each attribute can be conceptualized as expressing a particular explanatory variable.

We used a particular variety of conjoint analysis called choice-based conjoint analysis. We confronted participants in our surveys, in stylized form, with two potential trade partner countries at a time shown side-by-side. These two countries varied with respect to the eight different characteristics (attributes) that we hypothesized on in our theoretical argumentation. We then asked respondents to express their preferences in binary terms (i.e.

${ }^{5}$ Conjoint experiments of the type we use have thus far only been implemented online. Since online surveys turned out to be too difficult to implement in developing countries due to limited internet access and security issues, we designed a face-to-face application based on Strezhnev, Hainmueller, Hopkins, and Yamamoto (2013). More information on the technical details is available in the Appendix and from the authors on request.

${ }^{6}$ We used a stratified multi-stage probabilistic sampling strategy based on censal segments, moving first from the region/city level to the district level and then to the ward/commune/segment level where households and individuals were selected. First, districts were selected according to populated areas within each region/city, using systematic random selection with probability proportional to size. In the next stage, clusters or blocks of households were randomly selected from within the different districts. To ensure the diversity and representativeness of our sample, ten interviews were fixed for each cluster. This means 82 clusters in Costa Rica, 80 in Nicaragua and 70 in Vietnam. Households in each cluster were selected at a fixed interval, departing from a predefined point using the right hand rule. Respondents in the selected households were chosen based on the Kish Grid method. Gender and age quotas were used to generate a sample that is similar to the national distribution on these two variables. Appendix 1 shows socio-demographic data and its comparison with census figures. which of the two countries they prefer) and on a sevenpoint scale (i.e. how much they prefer each of the two countries). The latter measure is useful because the binary (forced choice) measure alone does not tell us the degree to which a respondent prefers one potential partner country over the other, nor does it take into account cases where a respondent prefers or dislikes both countries equally. Consequently, either respondents' choices or their ratings form our dependent variable, while PTA partner country attributes correspond to the explanatory variables in our hypotheses.

We asked respondents to complete five choice tasks in total, each of which consisted of profiles of two potential trade partner countries with a fixed set of attributes whose values varied between and across the choice tasks. Table 1 shows an example of such a choice task for the case of Vietnam. For each choice task respondents saw two new country profiles with randomly inserted values for each of the eight attributes. Because the attribute values are randomly assigned, we can then identify the causal effectthe Average Marginal Component Effect (AMCE)-of each attribute value on the probability that a particular profile will be chosen or rated as more/less desirable (Hainmueller et al. 2014).

Following our theoretical framework, we focus on eight attributes of potential trade partner countries: economic size and geographic distance (Hypothesis 1); language/ culture (Spanish in Costa Rica and Nicaragua, Lunar New Year celebrations in Vietnam) and religion (Hypothesis 2); political system (Hypothesis 3); military/security alliance (Hypothesis 4); and environmental and labor protection standards (Hypothesis 5). Table 2 offers an overview of attributes and their possible expressions (values). To allow for consistent testing of the hypothesis about political system type (Hypothesis 3) across the different contexts of the three countries, we avoided the term "democracy" and focused on what we regard as the most important element of democracy: the procedure for selecting political leadership.

The conjoint part of the survey started with a short introductory text ${ }^{f}$ and instructions for completing the choice tasks. Then we presented a table describing each of the attributes (see Table 2) before proceeding to the actual choice tasks (for further details, see Appendix 2). Using this setup, the unit of analysis is the country profile, with a maximum of 2 profiles $* 5$ choice tasks $*$ \# respondents; i.e. 8200 observations in the case of Costa Rica, 8000 for Nicaragua, and 7000 for Vietnam. We rescaled the second dependent variable's seven-point scale-where 1 indicates that the respondent would "never support" a PTA with the respective country and 7 indicates that she would "always support" a PTA with this country-to range from 0 to 1. Following Hainmueller et al. (2014), we estimate the AMCEs by regressing either the choice or the ranking variable on the different values of the attributes (for example, whether the potential partner country is a military ally), each of which is measured in binary form. We cluster

7"[Country] is currently negotiating international trade agreements with other countries. The purpose of such trade agreements is to make it easier for producers from other countries to sell their goods and services in [country] (imports), and to make it easier for producers based in [country] to sell their goods and services in other countries (exports). [Country] is considering different partner countries for such trade agreements. These partner countries may differ with respect to their characteristics. For a start, please look at the following table very carefully. It describes some basic characteristics partner countries for international trade agreements with [country] may have." 
Table 1. Example of conjoint choice task - Vietnam

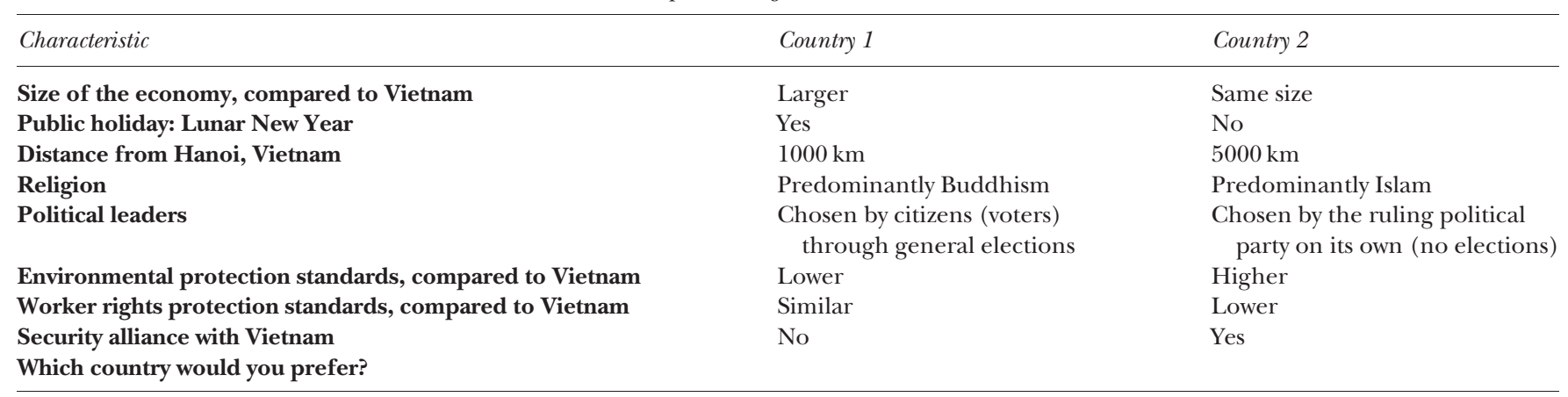

Table 2. Conjoint analysis - attributes and their values

\begin{tabular}{|c|c|}
\hline Attribute & Description, attribute values \\
\hline Size of the economy & $\begin{array}{l}\text { Partner countries may be of different economic size. Their economy may be smaller, } \\
\text { of similar size, or larger than the economy of [country]. } \\
\text { Values: Larger, same size, smaller }\end{array}$ \\
\hline Distance from & $\begin{array}{l}\text { The distance in kilometers between [capital] and the partner country's capital. } \\
\text { Values: } 1000 \mathrm{~km} ; 5000 \mathrm{~km} ; 10,000 \mathrm{~km}\end{array}$ \\
\hline Spanish (Costa Rica and Nicaragua only) & $\begin{array}{l}\text { Spanish may be widely spoken or not widely spoken in partner countries. } \\
\text { Values: Spoken by everyone, spoken by many, spoken by few }\end{array}$ \\
\hline Lunar New Year (Vietnam only) & $\begin{array}{l}\text { This country celebrates or not the Lunar New Year } \\
\text { Values: Yes, No }\end{array}$ \\
\hline Religion (Costa Rica and Nicaragua only) & $\begin{array}{l}\text { Partner countries may have a predominant religion like Christianity or Islam, or may } \\
\text { be religiously diverse with several religions practiced. } \\
\text { Values: Predominantly Christian, Predominantly Islam, Diverse }\end{array}$ \\
\hline Political leaders & $\begin{array}{l}\text { The political leaders of partner countries may be chosen by their citizens (voters) } \\
\text { through general elections, partly chosen by their citizens (voters) through general } \\
\text { elections, or chosen by the ruling political party on its own (no elections). } \\
\text { Values: Chosen by citizens (voters) through general elections, Partly chosen by citizens (voters) } \\
\text { through general elections, Chosen by the ruling political party on its own (no elections) }\end{array}$ \\
\hline Security alliance & $\begin{array}{l}\text { Partner countries may have or may not have a security alliance with [country]. } \\
\text { Values: Yes, no }\end{array}$ \\
\hline Environmental protection standards & $\begin{array}{l}\text { The environmental protection standards in partner countries may be stronger, similar, } \\
\text { or weaker, compared to the standards in [country]. } \\
\text { Values: Lower, similar, higher }\end{array}$ \\
\hline Worker rights protection standards & $\begin{array}{l}\text { The worker rights protection standards in partner countries may be stronger, similar, } \\
\text { or weaker, compared to the standards in [country]. } \\
\text { Values: Lower, similar, higher }\end{array}$ \\
\hline
\end{tabular}

standard errors on the respondent to account for the non-independence of their $(2 \times 5)$ choices.

Finally, we want to stress that we focus on abstract country attributes and do not refer to potential PTA partner countries by name (Gray and Hicks 2014). Mentioning specific partner countries by name would confound the treatment effects of our attributes and would prevent us from finding out which country characteristics are driving respondents' preferences. For instance, if we found that the United States is more attractive to Vietnamese respondents than China, we would not know whether the attractiveness has something to do with economic size, political system type, or other factors.

Though we use abstract attributes, respondents still might connect some of the choice profiles with specific countries. However, the odds of this confounding our estimates are extremely low. For example, in the case of Costa Rica, only about 7 of the 8200 de facto country profiles (that is, combinations of attribute values) correspond in abstract form (without the country name appearing anywhere) to the attribute values for the United States. Additionally, not only are attribute values randomly assigned, but the order of the listed attributes changes randomly as well, making it highly unlikely for respondents to base their decisions on unobserved thoughts or emotions concerning specific countries. As a robustness check, we excluded profiles that (coincidentally) closely resembled major potential PTA partners (in the case of Costa Rica, for instance, the European Union, the United States, and Nicaragua). Dropping these observations did not change the results.

\section{Results}

Figures 1.1 to 1.3 illustrate the findings for each country: dots represent the estimates for each attribute on the probability that an individual chooses the respective partner country profile, and horizontal lines represent the 95 percent confidence intervals. Interpretation of each attribute is relative to the (omitted) baseline category, which is depicted as a dot on the vertical zero line.

The results show that in spite of different national contexts, individuals in the three countries hold similar preferences regarding potential PTA partners. Starting with 


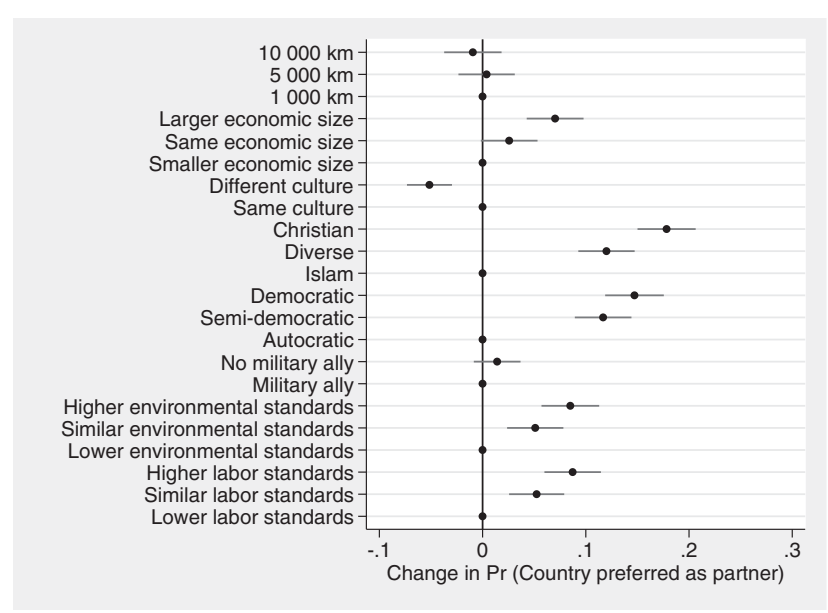

Figure 1.1. Results for Costa Rica

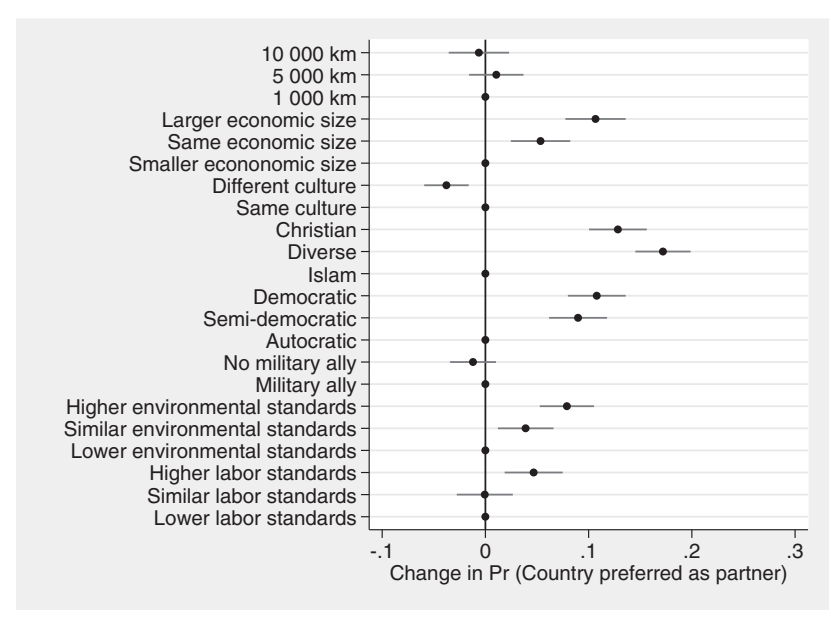

Figure 1.2. Results for Nicaragua

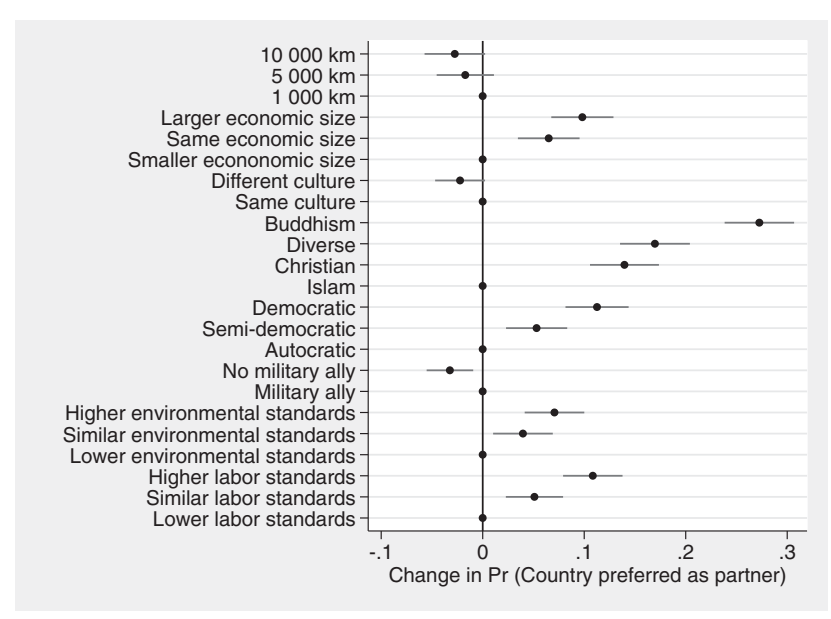

Figure 1.3. Results for Vietnam

the variables measuring consumer gains, it turns out that considerations related to distance do not affect evaluation of potential PTA partners. Only in Vietnam do we observe the negative and statistically almost significant effect of the largest distance $(10,000 \mathrm{~km})$ on PTA partner choice suggested by theory.
The second attribute measuring consumer gains, economic size, affects individual preferences as predicted by hypothesis 1 . In all our country samples, we observe that respondents prefer larger and similar-sized economies (with the exception of Costa Rica) over smaller economies. Larger economic size increases the probability of choosing a country by 7 percentage points in Costa Rica and 10.7 percentage points in Nicaragua. These findings support the hypothesis that individuals prefer to trade with larger economies because larger economies are associated with economic gains through increased consumption possibilities and access to larger export markets.

In line with hypothesis 2 , increases in psychic distance reduce support for a potential trade partner. With the exception of Vietnam, support drops if the potential partner country has a different culture: by about 4 percentage points in Nicaragua and 5 percentage points in Costa Rica. The effects of psychic distance for religion are even more pronounced: support increases by 17.8 percentage points in Costa Rica if the country is predominantly Christian relative to the baseline category of countries with an Islamic religious tradition. This increase is 12.8 percentage points in Nicaragua. The effect of Buddhism in the Vietnamese case is even more prominent, amounting to 27.3 percentage points. Interestingly, in all three countries individuals prefer countries with a diverse religious background to countries with an Islamic background. In Nicaragua, citizen support for countries with a diverse religious background is even higher (17.2 percentage points) than for countries with a Christian tradition. However, because the confidence intervals of both effects overlap, we cannot infer (at a statistically significant level) that Nicaraguans indeed prefer religiously diverse over Christian countries. Only in the Vietnamese case do we observe the effect of Buddhist religious tradition as significantly larger than the effects of diverse or Christian traditions, which are approximately of similar size.

After religion, political regime type has the second most powerful effect on PTA partner preferences. In all three countries, including autocratic Vietnam, a democratic partner country increases support by a minimum of 10.79 percentage points in Nicaragua to a maximum of 14.7 percentage points in Costa Rica. Interestingly, however, the effects of democracy and semi-democracy do not significantly differ in size in all three countries: while the increase in support for a democratic partner country is always higher than for a semi-democratic partner country, confidence intervals tend to overlap.

In our theoretical framework we argued that political regime type should matter for two reasons: shared value systems and rule of law. In the two democratic countries, Costa Rica and Nicaragua, both arguments speak in favor of citizens preferring democratic over autocratic partner countries. In Vietnam, only the rule of law argument is in line with a positive effect of democracy. However, drawing the conclusion that the prospect of greater compliance by democracies (due to stronger rule of law) is the main reason why democracies are considered more attractive trade partners would be far-fetched. Future research should thus focus in greater detail on the specific mechanisms potentially underlying the preference for democratic trading partners and more directly test whether rule of law or democratic institutions are more relevant to individual trade policy preferences. 

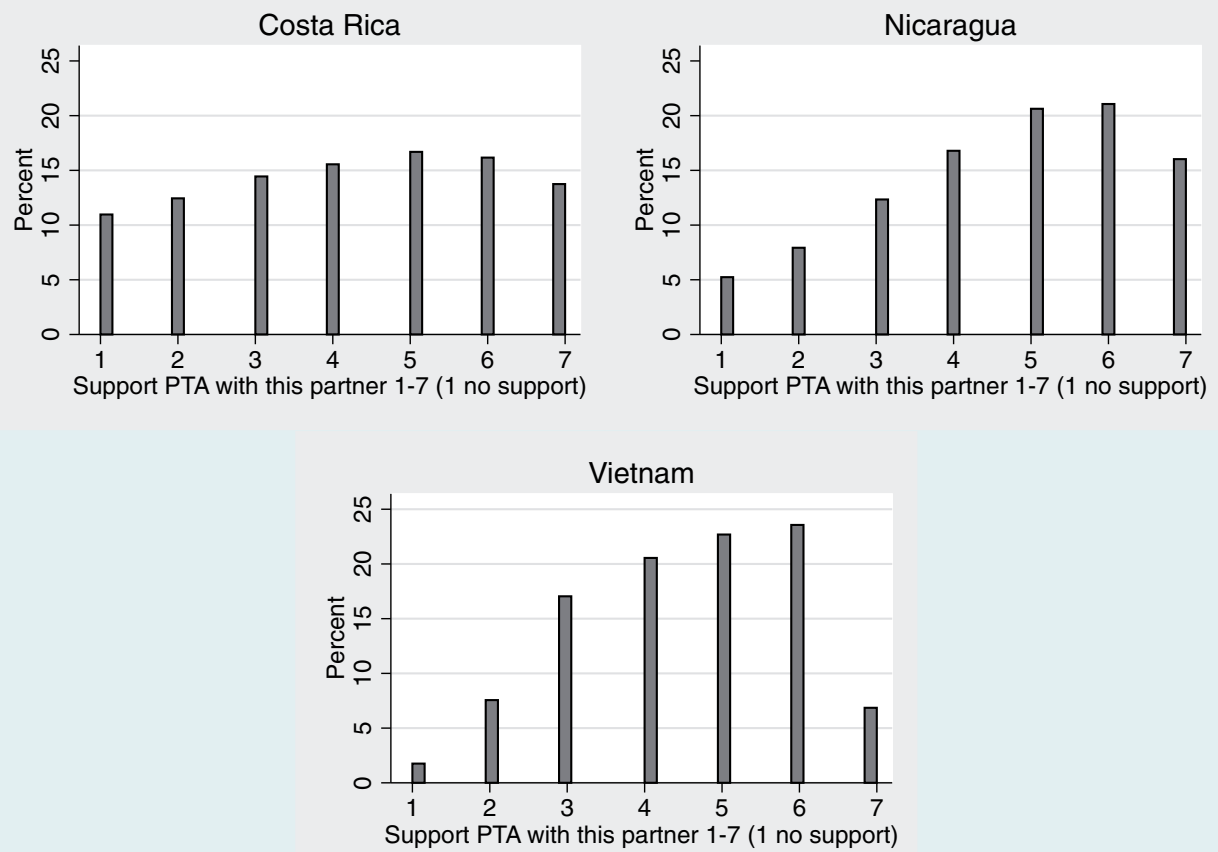

Figure 2. Overall support for potential trade partners, rating experiment results

We expected a country's historical background to mediate the effect of military alliances. In Costa Rica, a country that has had no army since 1949 and consistently pursues resolution of conflicts based on international law, we expected the effect of non-alliance to be less important or even insignificant, whereas it should be more pronounced in Nicaragua, which has previously been subjected to foreign (US) military and paramilitary interventions. The effect should be strongest in Vietnam, which is located in a region characterized by intense military-security rivalries, notably with China. The empirical results closely match the expected pattern: the effect of a security alliance is strongest in Vietnam (a non-ally country loses support by about 5.5 percentage points) and positive but non-significant in Costa Rica. In Nicaragua the effect is negative, as predicted, but not statistically significant from zero. Hence the results support, albeit to a limited degree, the idea that individuals worry that gains from trade could translate into military/security advantages when opting for a PTA partner country that is not a military ally.

Finally, with respect to environmental and labor standards, we argued that the level of economic development and the respondent's home country's standards are likely to influence whether citizens favor stricter environmental or labor standards in PTA partner countries. Following this logic, we only expected to see a positive effect in Costa Rica and not in Nicaragua and Vietnam, both of which compete on prices in labor and natural resource-intensive products.

However, results show that in all three countries, PTA partners with higher environmental and labor standards are more attractive than countries with similar or lower standards. The effects amount to four to eight percentage points in all three countries. Although the effect of stronger standards is most pronounced in Costa Rica, thus supporting hypothesis 5 , the confidence intervals again overlap making it impossible to statistically differentiate the effects in the three countries.

\section{Rating Results and Predicted PTA Partner Support}

As described above in the empirical design section, in addition to asking respondents to choose between two potential partner countries, we asked them to rate each proposed country on a 1 to 7 scale. These ratings allow us to obtain a more nuanced grasp of the strength of support for or opposition to specific types of PTA partners. It also permits assessment of the consistency of respondents' selections between the binary choice and the rating task.

We present detailed results of the rating task analysis in Appendix 3. While these results closely correspond to the results of the binary choice task, and thus demonstrate the robustness of our results, they also provide additional information. Most importantly, the rating task results allow for an overall assessment of how much individuals like PTAs in general and certain PTA partner countries specifically.

Figure 2 shows support levels across all potential trade partner countries for the three samples. The bars in the three panels indicate how many of the proposed (stylized) countries were rated as "1," implying no support at all for a PTA with the country, to " 7 ," implying strong support for a PTA with the country. We observe that PTAs are quite popular: the proportion of individuals giving responses of six or higher in the rating tasks based on all profiles vary from 37 percent in Nicaragua, to 30 percent in Vietnam and Costa Rica. Because of random assignment of the PTA partner characteristics, we can interpret these scores as expressing substantial demand for PTAs with other countries, irrespective of country type. ${ }^{8}$

Based on the rating estimates, we generated predicted levels of support for potential trade partner countries that combine characteristics that appear as explanatory variables in

\footnotetext{
${ }^{8}$ Expected values are based on the regression estimators with clustered standard errors; bars represent 95 percent confidence intervals. The dependent variable is the rating of each country profile.
} 


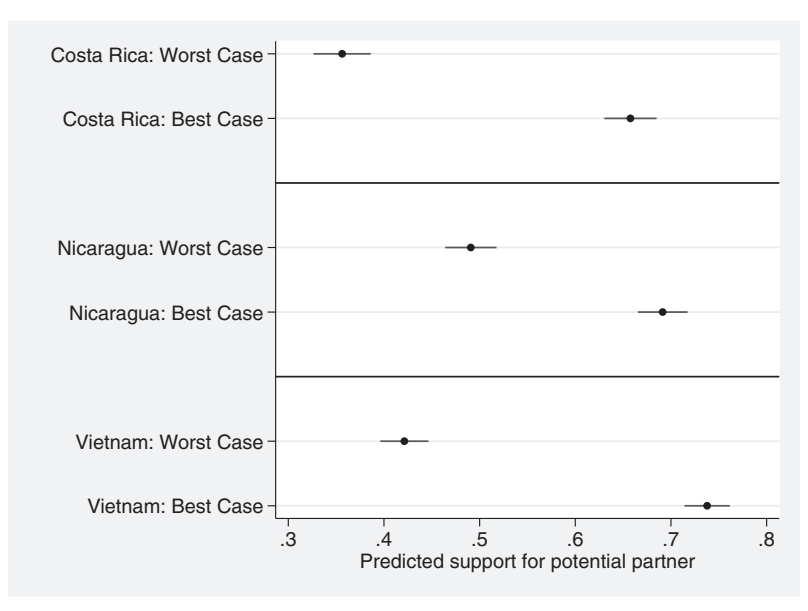

Figure 3. Expected support for a potential trade partner

our hypotheses. ${ }^{9}$ In Figure 3, we plot two ideal type scenarios: scenario one corresponds to a PTA partner combining all of the least preferred ${ }^{10}$ characteristics and scenario 2 corresponds to a PTA partner combining all of the most preferred $^{11}$ characteristics. Plotting these two ideal type scenarios against each other shows how support for a potential trade agreement depends on the eight hypothesized partner country characteristics. In the worst-case scenario (scenario one), the predicted levels of support are 0.36, 0.49, and 0.43 for Costa Rica, Nicaragua, and Vietnam, respectively (see Figure 3). In contrast, for the most preferred partners (scenario two), the predicted levels of support are 0.66, 0.69, and 0.74 for Costa Rica, Nicaragua, and Vietnam, respectively.

Additionally, data generated by the rating task allow us to check whether respondents provide consistent answers across the binary choice and rating tasks. To be consistent, a respondent who ranks a country of type A over type B in the binary choice task should also assign a higher rating to A than to B. To check whether respondents indeed provided consistent answers, we analyzed the proportion of inconsistencies in the three samples. In the Vietnamese sample, we do not observe any inconsistent ratings, in Costa Rica the inconsistency rate is 1.34 percent, and in Nicaragua, 6 percent. However, our main results do not change when we drop observations where participants expressed inconsistent preferences.

To further illustrate the substantive meaning of our results, we present a comparison of how well our findings correspond with the actual PTA partners of the three countries in Appendix 4. These comparisons show that in both Costa Rica and Nicaragua actual PTA partners align quite well with voter preferences, whereas in Vietnam, the sole autocratic country in our sample, PTA partner choices diverge more from citizens' preferences.

\footnotetext{
${ }^{9}$ The overall mean expected value for support on a $0-1$ scale is $0.53,0.61$, and 0.59 for Costa Rica, Nicaragua, and Vietnam, respectively.

${ }^{10}$ Here the country is relatively far away (more than $10,000 \mathrm{~km}$ ), is a small economy, has lower labor and environmental standards, is not a military ally and not a democracy, Islam is the predominant religion, and the country is not culturally similar (language for Costa Rica and Nicaragua, or does not celebrate Lunar Year for Vietnam).

${ }^{11}$ Here the potential trade partner is relatively close by (less than $1000 \mathrm{~km}$ away), is a large economy, has stronger environmental and labor standards, is a military ally and a democracy, Christianity (Buddhism for Vietnam) is the predominant religion, and the country is culturally similar (language for Costa Rica and Nicaragua, or Lunar Year celebration for Vietnam).
}

Finally, in Appendix 5 we show that our findings also hold in different subgroup analyses. In particular, we follow the literature on trade preferences and provide results for subsamples split according to individuals' skill level, income, and the salience of trade policy.

\section{Discussion and Conclusion}

The rapid proliferation of preferential trade agreements in the global economy raises a plethora of important questions concerning international cooperation. In contrast to the WTO framework, PTAs allow for discrimination with respect to trade concessions to other countries, making the reasons for PTA partner country selection a key question.

What makes a country a potentially attractive PTA partner? We know from macro-level studies on advanced industrialized countries that governments, on average, tend to opt for economically large, geographically close, democratic, and culturally similar trade partners. This study is the first to provide insights into how citizens in developing countries evaluate potential PTA partners. Based on the presumption that what citizens want matters in trade policy, we complement macro-level research by focusing on the micro-level in countries that are playing an increasingly important role in the global trading system but for which very little research on this issue exists (Hicks and Kim 2012).

Moreover, the research presented here contributes in several ways to the growing literature seeking to explain citizens' trade policy preferences (Baker 2003, 2005; Beaulieu 2002; Beaulieu et al. 2005; Blonigen 2008; 2011; Fordham and Kleinberg 2012; Mansfield and Mutz 2009; Mayda and Rodrik 2005; O'Rourke and Sinnott 2001; Scheve and Slaughter 2001). To the best of our knowledge, this is the first study that theoretically and empirically examines the multidimensionality of PTA partner country preferences at the micro level. By presenting experimental data from three developing countries, we thus extend the often narrow empirical focus of existing research on very few highly advanced industrialized countries, above all the United States (Blonigen 2008, 2011; Fordham and Kleinberg 2012; Guisinger 2009; Hainmueller and Hiscox 2006; Mansfield and Mutz 2009; Rho and Tomz 2012; Scheve and Slaughter 2001; an important recent exception is Lü, Scheve, and Slaughter 2012). ${ }^{12}$

Our results show that despite very different national contexts, citizens hold surprisingly similar preferences when it comes to desirable attributes of PTA partner countries. Though we expected individuals to react similarly to factors such as economic size and distance, we expected more differentiated reactions to the political system and environmental and labor standards. Interestingly, however, we observe that individuals in poorer and rapidly growing countries, such as Vietnam and Nicaragua, also prefer trade with countries that have higher environmental and labor standards. Similarly, not only do respondents in democratic Costa Rica and

${ }^{12} \mathrm{~A}$ few other studies focus on Canada (Beaulieu 2002), Switzerland (Bechtel, Bernauer, and Meyer 2012; Spilker, Schaffer, and Bernauer 2012), and Japan (Naoi and Kume 2011). Several studies also use data from international omnibus surveys, such as World Values Survey (Baker 2005; Mayda and Rodrik 2005; O'Rourke and Sinnott 2001), Eurobarometer (Gabel 1998; Hooghe and Marks 2004; Schaffer and Spilker 2016), and Latinobarómetro (Baker 2003; Beaulieu et al. 2005). Baker (2003) and Lü, Scheve, and Slaughter (2012) are, to our knowledge, the only studies that use original surveys to examine individual trade policy preferences in large developing countries, Brazil and China, respectively. 
Nicaragua prefer PTAs with (other) democracies, respondents in autocratic Vietnam favor democratic PTA partner countries as well. These results suggest that, in contrast to arguments about post-material value systems (Anderson 1997; Franzen and Meyer 2010; Inglehart 1995, 1997; Spilker 2013), public demand for standards concerning political participation and environmental and social rights is present and significant not only in industrialized countries, but also in developing nations as well. Therefore, these findings indicate that some important micro-level assumptions should be revisited, including those based on post-material value systems, on which several of the macro-level studies in this field are based (Anderson 1997; Franzen and Meyer 2010; Spilker 2013).

Despite the three countries' strong differences in income levels, political systems, and environmental and social standards, they are all small open economies. Thus, trade agreements might be more salient for them than for most large industrialized economies. This could be one of the reasons why we observe comparatively high overall support for PTAs. Hence future research should analyze PTA support from a more comparative perspective. This would also allow an assessment as to whether our results-concerning the similarity of individual preferences with regard to PTA partner characteristics-hold more generally.

Does the potentially high salience of PTAs mean that our results offer no insights beyond the study of small, open developing economies? Arguably, at least two arguments speak against such limitation. First, when we split our samples according to salience (see Appendix 5), citizens who consider trade an important issue prefer very similar trading partners compared to citizens who have not thought much about trade issues before. To us, this underlines the fact that the salience of the topic of international trade does not affect the characteristics people tend to value in their preferred trading partners. This receives further support because we find similar results in another study with US respondents (Umaña, Bernauer, and Spilker 2015).

Furthermore, our results add to a growing debate regarding whether individuals form trade preferences mainly on economic self-interest or on other, noneconomic factors. While our results indicate that economic factors, such as a PTA partner's economic size, are relevant, other partner characteristics, such as cultural similarity, the political system, and environmental and labor standards, are at least as important. These findings support the view that models of individual trade preferences focusing mainly on economic self-interest (Mayda and Rodrik 2005; O'Rourke and Sinnott 2001; Scheve and Slaughter 2001) are too narrowly conceived. Rather, it seems individuals do not merely maximize their pocketbook, thus highlighting the need to explore causes beyond mere economic self-interest to explain individual trade preferences (Mansfield and Mutz 2009; Fordham and Kleinberg 2012; Rho and Tomz 2012).

The importance of non-material factors-in particular, psychic distance (cultural proximity) and basic political value systems-also speaks to literature's emphasizing identity and collective identification (Ariely 2012; Herrmann, Isernia and Segatti 2009; Huddy 2001, 2004). Since understanding the implications of trade agreements on the personal level is a complex and difficult task, individuals often rely on signals and cues—such as cultural similarity and similarity of basic political values (democracy) - in order to evaluate the attractiveness of potential trade partners.

The research reported in this paper also underscores the importance of unpacking the theoretical and empirical multidimensionality inherent in many policy choices, including those in the realm of international trade. Preferring one PTA partner over another involves weighing several characteristics of the potential trade partner against each other. While this study provides a first step in this direction, future research could delve more into the details of what factors mediate the effects of some partner country characteristics, such as cultural similarity or economic size.

Overall, our empirical findings show that PTA partner preferences cannot be reduced to one single factor. It is rather the presence of several characteristics, such as economic size, political system, and cultural similarity that induce support levels for potential partners and generate variation in support reaching from 36 percent to 74 percent. This finding is also relevant to policy-making: it shows that in spite of widespread skepticism against trade liberalization and economic globalization, international trade agreements can achieve very high levels of support if the "right" partner countries are involved. In this context, it is worthy of note that prevailing public demand for particular PTA partner country types lines up quite well with actual PTA partner countries in the cases of Costa Rica and Nicaragua, while in Vietnam actual government PTA partner choices diverge more significantly from citizens' preferences.

\section{References}

Acharya, Amitav, and Barry Buzan. 2007. "Why Is There No Non-Western International Relations Theory? An Introduction." International Relations of the Asia-Pacific 7(3): 287-312.

Anderson, Kym. 1997. "Social Policy Dimensions of Economic Integration: Environmental and Labor Standards." In Regionalism versus Multilateral Trade Arrangements, edited by Takatoshi Ito, and Anne O Krueger, 57-90. Chicago: University of Chicago Press

Ariely, Gal. 2012. "Globalization, Immigration and National Identity: How the Level of Globalization Affects the Relations between Nationalism, Constructive Patriotism and Attitudes toward Immigrants?" Group Processes E Intergroup Relations 15(4): 539-57.

Baccini, Leonardo, and Andreas Dür. 2012. "The New Regionalism and Policy Interdependence." British Journal of Political Science 42(1): 57-79.

Baccini, Leonardo, and Johannes Urpelainen. 2012. "Strategic Side Payments: Preferential Trading Agreements, Economic Reform, and Foreign Aid." The Journal of Politics 74(4): 932-49.

Baier, Scott L., and Jeffrey H. Bergstrand. 2004. "Economic Determinants of Free Trade Agreements." Journal of International Economics 64(1): 29-63.

Baier, Scott L., Jeffrey H. Bergstrand, and Matthew W. Clance. 2014. "Preliminary Examination of Heterogeneous Effects of Free Trade Agreements." In Trade Cooperation: The Purpose, Design and Effects of Preferential Trade Agreements, edited by Andreas Dür and Manfred Elsig, 355-73. Cambridge: Cambridge University Press

Baker, Andy. 2005. "Who Wants to Globalize? Consumer Tastes and Labor Markets in a Theory of Trade Policy Beliefs." American Journal of Political Science 49: 924-38.

—. 2003. "Why Is Trade Reform so Popular in Latin America? A Consumption-Based Theory of Trade." World Politics 55: 423-55.

Baldwin, Richard E. 2011. "21st Century Regionalism: Filling the Gap Between 21st Century Trade and 20th Century Trade Rules." WTO Staff working paper ERSD. Geneva: In association with WTO.

Beaulieu, Eugene. 2002. "Factor or Industry Cleavages in Trade Policy? An Empirical Analysis of the Stolper-Samuelson Theorem." Economics E Politics 14(2): 99-131.

Beaulieu, Eugene, Ravindra A. Yatawara, and Wei Guo Wang. 2005. "Who Supports Free Trade in Latin America?" The World Economy 28(7): 941-58

Bechtel, Michael M., Thomas Bernauer, and Reto Meyer. 2012. "The Green Side of Protectionism: Environmental Concerns and Three 
Facets of Trade Policy Preferences." Review of International Political Economy 19(5): 837-66.

Bernauer, Thomas, and Tobias Böhmelt. 2013. "Are Economically 'Kinder, Gentler Societies' also Greener?” Environmental Science Ev Technology 47(21): 11993-2001.

Bernauer, Thomas and Quynh Nguyen. 2015. "Trade and/or Environmental Protection?" Global Environmental Politics (forthcoming).

Blonigen, Bruce A. 2011. "Revisiting the Evidence on Trade Policy Preferences." Journal of International Economics 85(1): 129-35.

Blonigen, Bruce Aloysius. 2008. "New Evidence on the Formation of Trade Policy Preferences.” NBER Working Paper (14627): 1-39

Caves, Richard, Frankel Jeffrey, and Jones Ronald. 2002. World Trade and Payments. An Introduction. Boston: Addison Wesley.

Cottier, Thomas. 2002. "Trade and Human Rights: A Relationship to Discover." Journal of International Economic Law 5(1): 111-32.

Dow, Douglas. 2006. "Factors Moderating the Impact of Psychic Distance: Empirical Tests on Bi-Lateral Trade Flows." Proceedings of the 48th Annual Meeting of the AIB, Beijing, China.

Dow, Douglas, and Karunaratna. Amal 2006. "Developing a Multidimensional Instrument to Measure Psychic Distance Stimuli." Journal of International Business Studies 37(5): 578-602.

Drezner, Daniel W. 2008. "The Realist Tradition in American Public Opinion." Perspectives on Politics 6(1): 51-70.

Dür, Andreas, Leonardo Baccini, and Manfred Elsig. 2014. "The Design of International Trade Agreements: Introducing a New Dataset." The Review of International Organizations: 9(3): 353-75.

Egger, Peter, and Mario Larch. 2008. "Interdependent Preferential Trade Agreement Memberships: An Empirical Analysis.” Journal of International Economics 76(2): 384-99.

Ehrlich, SEAn D. 2010. "The Fair Trade Challenge to Embedded Liberalism." International Studies Quarterly 54: 1013-33.

Epi. 2014. Environmental Performance Index. "Environmental Performance Index". Accessed March 8, 2014. http://epi.yale.edu.

Ferrantino, Michael J. 1997. "International Trade, Environmental Quality and Public Policy.” The World Economy 20(1): 43-72.

Fordham, Benjamin O, and Katja B. Kleinberg 2012. "How Can Economic Interests Influence Support for Free Trade?" International Organization 66(2): 311-28.

Fordham, Benjamin O., and Katja B. Kleinberg 2011. "International Trade and US Relations with China." Foreign Policy Analysis 7(3): 217-36.

Frankel, Jefrrey A., Ernesto Stein, and Shang-Jin Wei. 1998. Continental Trading Blocs: Are They Natural or Supernatural? In The Regionalization of the World Economy, edited by Jeffrey A Frankel, 91-120. University of Chicago Press.

Franzen, Axel, and Reto Meyer. 2010. "Environmental Attitudes in CrossNational Perspective: A Multilevel Analysis of the ISSP 1993 and 2000.” European Sociological Review 26(2): 219-34.

Gabel, Matthew. 1998. "Public Support for European Integration: An Empirical Test of Five Theories." Journal of Politics 60(2): 333-54.

Gowa, Joanne, and Edward D. Mansfield. 1993. "Power Politics and International Trade." American Political Science Review 87(2): 408-20.

Gray, Julia, and Raymond Hicks. 2014. "Reputations, Perceptions, and International Economic Agreements." International Interactions: Empirical and Theoretical Research in International Relations 40(3): 325-49.

Green, Paul, Abba M. Krieger, and Yoram Wind. 2001. "Thirty Years of Conjoint Analysis: Reflections and Prospects." Interfaces 31(3 supplement): 56-S73.

Grieco, Joseph M. 1988. "Realist Theory and the Problem of International Cooperation: Analysis with an Amended Prisoner's Dilemma Model." Journal of Politics 50(3): 600-24.

Grossman, Gene M., and Elhanan Helpman. 1995. "The Politics of FreeTrade Agreements." The American Economic Review 85: 667-90.

Guisinger, Alexandra. 2009. "Determining Trade Policy: Do Voters Hold Politicians Accountable?" International Organization 63(3): 533-557.

Guiso, Luigi, Paola Sapienza, and Luigi Zingales. 2009. "Cultural Biases in Economic Exchange?" The Quarterly Journal of Economics 124(3): 1095-131.

Hafner-Burton, Emilie M. 2005. "Trading Human Rights: How Preferential Trade Agreements Influence Government Repression.” International Organization 59(3): 593-629.
Hainmueller, Jens, Daniel J Hopkins, and Teppei Yamamoto. 2014. "Causal Inference in Conjoint Analysis: Understanding Multidimensional Choices via Stated Preference Experiments.” Political Analysis 22(1): $1-30$.

Hainmueller, Jens, and Michael J. Hiscox. 2006. "Learning to Love Globalization: Education and Individual Attitudes Toward International Trade." International Organization 60(2): 469-98.

Hearn, EdDIE. 2013. "National Images and Trade Attitudes:An Experimental Examination of Consumer Support for Bilateral Trade." Working Paper: 1-35.

Herrmann, Richard K., Pierangelo Isernia, and Paolo Segatti. 2009. "Attachment to the Nation and International Relations: Dimensions of Identity and their Relationship to War and Peace." Political Psychology 30(5): 721-54.

Hicks, Raymond, Helen V Milner, and Dustin H. Tingley. 2014. "Trade Policy, Economic Interests, and Party Politics in a Developing Country: The Political Economy of CAFTA-DR.” International Studies Quarterly 58(1): 106-17.

Hicks, Raymond, and Soo Yeon Kim. 2012. "Reciprocal Trade Agreements in Asia: Credible Commitment to Trade Liberalization or Paper Tigers?" Journal of East Asian Studies 12(1): 1-29.

Hooghe, Liesbet, and Gary Marks. 2004. "Does Identity or Economic Rationality Drive Public Opinion on European Integration?" Political Science and Politics 37(3): 415-20.

Hornbeck, J. F. 2008. The Dominican Republic-Central America-United States Free Trade Agreement (CAFTA-DR). 1-114. Washington DC: Congressional Research Service.

Huddy, LeONIE. 2001. "From Social to Political Identity: A Critical Examination of Social Identity Theory." Political Psychology 22(1): 127-56.

Huddy, LeoniE. 2004. "Contrasting Theoretical Approaches to Intergroup Relations.” Political Psychology 25(6): 947-67.

Inglehart, Ronald. 1997. Modernization and Postmodernization: Cultural, Economic, and Political Change in 43 Societies. Princeton, NJ: Princeton University Press.

- 1995. "Public Support for Environmental Protection: Objective Problems and Subjective Values in 43 Societies." Political Science and Politics 28(1): 57-72.

Kaltenthaler, Karl C, and William J Miller. 2013. "Social Psychology and Public Support for Trade Liberalization." International Studies Quarterly 57(4): 784-90.

Klein, Jill Gabrielle, Richard Ettenson, and Marlene D. Morris. 1998. "The Animosity Model of Foreign Product Purchase: An Empirical Test in the People's Republic of China." The Journal of Marketing 62: 89-100.

Klein, Jill Gabrielle. 2002. "Us versus Them, or Us versus Everyone? Delineating Consumer Aversion to Foreign Goods." Journal of International Business Studies: 345-63.

Kono, Daniel Y. 2008. "Does Public Opinion Affect Trade Policy?" Business and Politics 10(2): 1-21.

Li, Quan. 2006. "Democracy, Autocracy, and Tax Incentives to Foreign Direct Investors: A Cross-National Analysis." Journal of Politics 68(1): 62-74.

Liberman, Peter. 1996. "Trading with the Enemy: Security and Relative Economic Gains.” International Security 21(1): 147-75.

Linders, Gert-Jan M., Martijn J. Burger, and Frank G. van Oort. 2008. "A Rather Empty World: The Many Faces of Distance and The Persistent Resistance To International Trade." Cambridge Journal of Regions, Economy and Society 1(3): 439-58.

Liu, Xuepeng. 2010. "Testing Conflicting Political Economy Theories: Full-Fledged Versus Partial-Scope Regional Trade Agreements." Southern Economic Journal 77(1): 78-103.

Loan, Nguyen Thi Phuong. 2011. "Problems of Law Enforcement in Vietnam:The Case of Wastewater Management in Can Tho City." Center for Development Research (ZEF). Working Paper Series (53): 1-124.

Lü, Xiaobo, Kenneth F. Scheve, and Matthew J. Slaughter. 2012. "Inequity Aversion and the International Distribution of Trade Protection." American Journal of Political Science 56(3): 638-54.

Manger, Mark S., and Kenneth C. Shadlen. 2014. "Political Trade Dependence and North-South Trade Agreements." International Studies Quarterly 58(1): 79-91.

Mansfield, Edward D., and Diana C. Mutz. 2009. "Support for Free Trade: Self-Interest, Sociotropic Politics, and Out-Group Anxiety." International Organization 63(3): 425-57.

Mansfield, Edward D., And Helen V. Milner. 2014. The Political Economy of Preferential Trade Agreements. In Trade Cooperation: The Purpose, 
Design and Effects of Preferential Trade Agreements, edited by Andreas Dür and Manfred Elsig, 56-81. Cambridge: Cambridge University Press.

Mansfield, Edward D., and Helen V. Milner. 2012. Votes, Vetoes, and the Political Economy of International Trade Agreements. Princeton, NJ: Princeton University Press.

Mansfield, Edward D., Helen V. Milner, and Jon C. Pevehouse. 2008. "Democracy, Veto Players and the Depth of Regional Integration." The World Economy 31(1): 67-96.

Marshall, Monty G., Keith Jaggers, and Ted R. Gurr. 2006. Polity IV Project: Political Regime Characteristics and Transitions, 1800-2009. "Center for Systemic Peace." Accessed May 27, 2014. http://www.systemicpeace.org/polity/polity4.html

Mayda, Anna Maria, and Dani Rodrik. 2005. "Why Are Some People (and Countries) More Protectionist than Others?" European Economic Review 49(6): 1393-430.

Morrow, James D., Randolph M. Siverson, and Tressa E. Tabares. 1998. "The Political Determinants of International Trade: The Major Powers, 1907-90." American Political Science Review 92(3): 649-8761.

Naoi, Megumi, and Ikuo Kume. 2011. "Explaining Mass Support for Agricultural Protectionism: Evidence from a Survey Experiment During the Global Recession." International Organization 65: 771-95.

Nguyen, Quynh, and Thomas Bernauer. 2014. "Does Social Trust increase Support for Free Trade? Evidence from a Field Survey Experiment in Vietnam." World Trade Institute Working Paper (13).

O'Rourke, Kevin H., and Richard Sinnott. 2001. "The Determinants of Individual Trade Policy Preferences: International Survey Evidence." Brookings Trade Forum 2001 2001(1): 157-96.

OAtley, Thomas. 2010. International Political Economy. Boston: Longman.

Porter, Michael E, Scott Stern, and Michael Green. 2014. "Social Progress Index 2014.” Social Progress Imperative, 1-116. Accessed April 7, 2014. http://www.socialprogressimperative.org/data/spi.

Rauch, James E. 1999. "Networks versus Markets in International Trade." Journal of International Economics 48(1): 7-35.

Rho, Sungmin, and Michael Tomz. 2012. "Industry, Self-Interest, and Individual Preferences over Trade Policy.” Working Paper, Paper presented at the Annual Meeting of the International Political Economy Society. University of Virginia, Charlottesville, VA. 1-35.

Russett, Bruce M., and John R. Oneal. 2001. Triangulating Peace: Democracy, Interdependence, and International Organizations. New York: Norton.

Sala-I-Martin, Xavier, and Klaus Schwab. 2012. The Global Competitiveness Report 2012-2013. Geneva: World Economic Forum.

Sattler, Thomas, and Thomas Bernauer. 2011. "Gravitation or discrimination? Determinants of litigation in the World Trade Organisation." European Journal of Political Research 50(2): 143-67.

Schaffer, Lena Maria, and Gabriele Spilker. Forthcoming 2016. "Adding Another Level: Individual Responses to Globalization and Government." Political Science Research and Methods.
Scheve, Kenneth F, and Matthew J Slaughter. 2001. "What Determines Individual Trade-Policy Preferences?" Journal of International Economics 54(2): 267-92.

Shadlen, Kenneth C. 2005. "Exchanging Development for Market Access? Deep Integration and Industrial Policy under Multilateral and Regional-Bilateral Trade Agreements." Review of International Political Economy 12(5): 750-75.

2008. "Globalisation, Power and Integration: The Political Economy of Regional and Bilateral Trade Agreements in the Americas." Journal of Development Studies 44(1): 1-20.

Simmons, Beth A., and Zachary Elkins. 2004. "The Globalization Of Liberalization: Policy Diffusion in the International Political Economy." American Political Science Review 98(1): 171-89.

Spilker, Gabriele. 2013. Globalization, Political Institutions and the Environment in Developing Countries. New York: Routledge.

Spilker, Gabriele, and Tobias Böhmelt. 2013. "The Impact of Preferential Trade Agreements on Governmental Repression Revisited." The Review of International Organizations 8(3): 343-61.

Spilker, Gabriele, Lena Maria Schaffer, and Thomas Bernauer. 2012. "Does Social Capital Increase Public Support for Economic Globalisation?" European Journal of Political Research 51(6): 756-84.

Strezhnev, Anton, Jens Hainmueller, Daniel J Hopkins, and Teppei Yамамото 2013. "Conjoint Survey Design Tool: Software Manual." Accessed February 17, 2014. http://scholar.harvard.edu/files/ astrezhnev/files/conjoint_sdt_manual_0.pdf.

Tinbergen, Jan. 1962. "An Analysis of World Trade Flows." In Shaping the World Economy, edited by Jan Tinbergen, 1-117. New York: Twentieth Century Fund.

Tomz, Michael, and Jessica Weeks. 2013. "Public Opinion and the Democratic Peace.” American Political Science Review 107(4): 849-65.

Umaña, Víctor Thomas Bernauer, and Gabriele Spilker. 2015. Natural Trading Partners? A Public Opinion Perspective on Preferential Trade Agreements. In Trade Cooperation: The Purpose, Design and Effects of Preferential Trade Agreements, edited by Andreas Dür and Manfred Elsig, 113-33. Cambridge: Cambridge University Press.

Urbatsch, Robert. 2013. "A Referendum on Trade Theory: Voting on Free Trade in Costa Rica.” International Organization 67(1): 197-214.

Verlegh, Peeter WJ, and Jan-Benedict Em Steenkamp. 1999. "A Review and Meta-analysis of Country-of-origin research." Journal of Economic Psychology 20(5): 521-46.

Vietnam News. 2013. Environmental Laws Need Improvement. vietnamnews.vn. Accessed May 19, 2014. http://vietnamnews.vn/environ ment/247164/environmental-laws-need-improvement.html. 